\title{
TUBULIN, A POSSIBLE MARKER FOR THE PROGNOSTIC STRATIFICATION AND THERAPY IN PAPILLARY THYROID CARCINOMA
}

\author{
DELIA CIOBANU ${ }^{1,2}$, IRINA-DRAGA CĂRUNTU $^{1 *}$, LUDMILA LOZNEANU $^{1,2}$, ELENA \\ CORINA ANDRIESCU ${ }^{1,2}$, LETIȚIA LEUȘTEAN ${ }^{3,4}$, SIMONA ELIZA GIUȘCA $^{1}$ \\ ${ }^{I}$ Department of Morpho-functional Sciences I, University of Medicine and Pharmacy "Grigore T. Popa", Iași, Romania \\ ${ }^{2}$ Department of Pathology, "Sf. Spiridon" County Clinical Emergency Hospital, Iași, Romania \\ ${ }^{3}$ Department of Medical Specialities II, University of Medicine and Pharmacy "Grigore T. Popa", Iaşi, Romania \\ ${ }^{4}$ Department of Endocrinology, "Sf. Spiridon” County Clinical Emergency Hospital, Iași, Romania
}

*corresponding author: irinadragacaruntu@gmail.com

\begin{abstract}
The present study aims to analyse the expression of class III $\beta$-tubulin (TUBB3) in different histological subtypes of papillary thyroid carcinoma (PTC), its relationship with the clinico-pathological factors and the potential prognostic role in the risk stratification and therapy. We evaluated the immunohistochemical TUBB3 expression in 70 cases of sporadic PTC divided in low- and high-risk subgroups based on histological criteria. We demonstrated a significant correlation between TUBB3 expression (low and moderate versus high) and the risk subgroups and tumour relapse, respectively. No association was found between TUBB3 expression and age, gender, tumour size, tumour focality, lympho-vascular invasion, extrathyroidal extension, lymph node metastases and tumour stage. Our results sustain the potential of TUBB3 as marker for prognostic stratification. Consequently, the therapy with taxanes, anti-microtubule agents that inhibit mitosis by disrupting microtubules, could be considered in the aggressive PTC cases that need a personalized therapy.
\end{abstract}

\section{Rezumat}

Scopul prezentului studiu este de a analiza expresia $\beta$-tubulin III (TUBB3) în diferite subtipuri histologice de carcinom tiroidian papilar (CTP), relația TUBB3 cu factorii clinicopatologici și potențialul rol prognostic în evaluarea riscului și terapie. Expresia imunohistochimică a TUBB3 a fost evaluată în 70 cazuri de CTP sporadic, împărțite în două subgrupuri în funcție de criterii histologice, cu risc scăzut și cu risc înalt. A fost demonstrată o corelație semnificativă între expresia TUBB3 (scăzută și moderată versus înaltă) și subgrupurile de risc, respectiv recidiva tumorală. Nu au existat diferențe semnificative statistic între expresia TUBB3 și vârstă, sex, dimensiune tumorală, focalitate, invazie limfo-vaculară, extensie extratiroidiană, metastază nodală şi stadiu tumoral. Rezultatele obţinute susțin potențialul TUBB3 ca marker prognostic pentru stratificare. Consecutiv, terapia cu taxani, agenți anti-microtubulari care inhibă mitoza prin dezasamblarea microtubulilor, ar putea fi luată în considerare pentru cazurile de CTP agresiv care necesită o terapie personalizată.

Keywords: tubulin, papillary thyroid carcinoma, risk stratification, therapy

\section{Introduction}

Thyroid carcinomas are the most frequent endocrine tumours, with a frequency of $1-3 \%$ of malignant tumours, and a higher incidence in females than in males [32, 40, 42]. World Health Organization (WHO) classifies thyroid carcinomas into four categories: papillary, follicular, medullary and anaplastic [42]. Papillary thyroid carcinoma (PTC) accounts for 70 $85 \%$ of all thyroid carcinomas and hence it is considered the most common type [62].

PTC incidence is exponentially increasing worldwide, fact which can be explained by deeper diagnostic experience associating high-resolution medical imaging, fine needle aspiration biopsy, pathological, immunehistochemical and molecular exams [54, 81]. PTC prognostic is generally favourable, with long-term life expectancy [40, 42]. Nevertheless, there are cases where the lymph node or distant metastases occur rapidly and the survival is poor [40, 41, 61, 67, 77]. To identify the cases with poor prognostic is crucial at the time of diagnosis. Therefore, new prognostic factors should be confirmed to allow a prognostic stratification and, implicitly, a different therapeutic management [68].

Not less than 15 histological variants of PTC are described: conventional, follicular, oncocytic, with columnar cells, tall cells or clear cell, diffuse sclerosing, solid, cribriform, macrofollicular, hobnail, with stroma "fasciitis-like", microcarcinoma, mixed and dediffentiated forms $[40,41]$. Some of these histological forms namely the solid tumours, tumours with tall or cylindrical cells, "hobnail" variant, the angioinvasive follicular papillary carcinomas, or those that associate 
poorly differentiated areas, squamous or anaplastic, seem to have a poorer prognostic [26, 27, 40].

The possibility for certain histological variants of PTC to be defined as high-risk or low-risk for an unfavourable outcome is highly debated. This classification can open perspectives for an individualized, more aggressive therapy, applied to the cases with poor prognostic, compared to the classical treatment of PTC [26, 27, 72].

On the other hand, a large gallery of molecular markers is analysed, following their validity as prognostic factors for PTC [68]. Unfortunately, despite the large number of studies focused on this topic, the results are still controversial. Consequently, the research interest is continuously enlarged, new candidates being added in the molecular gallery. One of these molecules is tubulin.

Microtubules are cytoskeletal proteins, made of two categories of $\alpha$ and $\beta$ tubulin heterodimers, with multiple isotypes and with a varied, specific composition compared to the type of tissue and the intra-cellular functions. Microtubules contribute to maintaining the cellular form and also to the intracellular transport and chromosomal segregation during mitosis, with the consecutive formation of the mitotic spindle [29, 52]. Multiple studies proved the implication of class III of $\beta$-tubulin (TUBB3) in the malignant cell transformation and the appearance of carcinomas. Higher levels of TUBB3 are reported in brain, lung, colorectal, ovarian, prostate and laryngeal carcinomas $[6,15,21,29,33,35,78,84,86]$. The analysis of TUBB3 expression in relation to therapy showed differences in response and resistance to treatment. TUBB3 overexpression is associated to a poor prognostic and, frequently, to chemoresistance to the neo-adjuvant therapy with taxanes of neo-adjuvant chemotherapy with a role in microtubules stabilization [43], used in lung, uterus, ovary, colon or breast cancer [14, 44, 69, 76].

Strictly referring to the thyroid tumour pathology, literature review indicates few papers that analyse TUBB3 in anaplastic cell thyroid carcinoma and the treatment with anti-microtubule agents that inhibit mitosis by disrupting microtubules $[1,18]$. To the best of our knowledge, there are only two studies that focuses on TUBB3 expression in PTC $[10,11]$. Within this context, our study analyses the TUBB3 expression in different histological subtypes of PTC and its relationship with the classical clinico-pathological factors, aiming to bring evidences for its potential prognostic role in the risk stratification and, possible, in therapy.

\section{Materials and Methods}

\section{Patients}

We analysed 70 cases of sporadic papillary thyroid carcinoma diagnosed at the Pathology Department of “Sf. Spiridon” Emergency County Hospital, Iași, Romania, from 2010 to 2016. The research was approved by the Ethics Committee of "Grigore T. Popa" University of Medicine and Pharmacy in Iași, Romania, pursuant to the ethical standards of Helsinki declaration regarding the patients' informed consent to the use of biologic material for scientific purpose. All the patients underwent total thyroidectomy, and in 41 cases regional lymphadenectomy was also performed. The patients' clinico-pathological characteristics (age, gender, tumour size, and lymph node metastases) were obtained from the medical files.

The cases were reassessed by three pathologists who agreed on the histological variant of PTC, multifocality, lympho-vascular invasion and the extrathyroidal extension (tumour cells present into perithyroidal soft tissues, beyond the thyroid capsule). They also chose the appropriate paraffin-embedded tissue fragment for the immunohistochemical exam. Based on the histological variants of PTC, the study group was divided into two subgroups, namely lowand high-risk. The low-risk subgroup included conventional and follicular variants, characterized by indolent behaviour and favourable prognosis $[26,27,40]$. The high-risk group included columnar cell, tall cell, cribriform, hobnail, diffuse sclerosing, solid, angioinvasive follicular, conventional with dedifferentiation to squamous cell carcinoma and oncocytic with undifferentiated solid areas variants, known as aggressive subtypes in clinical course and poorer prognosis [26, 27, 40].

Immunohistochemistry

Tissue sections as thick as $4 \mu \mathrm{m}$ were cut from paraffin blocks and disposed on slides coated with poli-L-lysine to ensure a better adhesion of the tissue. The slides were then dewaxed in xylene and rehydrated in four baths of ethanol with decreasing concentrations $(100 \%$, $90 \%, 80 \%$ and $70 \%$ ). In order to unmask the antigen, it was used the Heat-Induced Epitope Retrieval (HIER) technique, by immersing the slides in $\mathrm{pH} 6$ citrate buffer and heated in a water bath at $98^{\circ} \mathrm{C}$ for 30 minutes. The slides were left to cool at room temperature, rinsed in distilled water and incubated with hydrogen peroxide $3 \%$ for 10 minutes to block the endogenous peroxidases. Afterward, the primary antibody for $\beta$ /beta-tubulin 3 (rabbit polyclonal, Thermo Scientific, USA), at a dilution 1:200, was applied, and the slides were incubated overnight at $4^{\circ} \mathrm{C}$. The amplification of the immune reaction was made by using appropriate secondary and tertiary antibodies of the UltraVision Quanto Detection System HRP DAB (Thermo Scientific, USA). The reaction was developed with 3.3'-diaminobenzidine tetrahydrochloride chromogen (Thermo Scientific, USA). The sections were counterstained with Lillie's modified Haematoxylin. The correctness of the technique was 
simultaneously checked, running both positive and negative controls.

Semi-quantitative assessment

For the assessment of TUBB3 it was used the score proposed for small cell lung carcinoma [57], based on the percentage of positive tumour cells and the intensity of the immune-reaction, as follows: high expression for $>50 \%$ positive tumour cells and strong intensity of immune-reaction $(3+)$, moderate expression for $>50 \%$ positive tumour cells and moderate immune-intensity ( $2+$ ), and low expression for $\leq 50 \%$ positive tumour cells and/or moderate or low immunostaining $(\leq 2+)$.

Statistical analyses

The data were analysed using the Chi-square test (Maximum-Likelihood, Yates and Mantel-Haenszel) (SPSS V.19 - SPSS Inc., IBM Corporation, Chicago, IL, USA). Statistical significance was considered for $\mathrm{p}<0.05$.

\section{Results and Discussion}

\section{Clinico-pathological outline}

The study group comprised $53(75.72 \%)$ women and 17 men (24.28\%). The age at diagnosis ranged between 17 and 86 years old with a mean of $49.27 \pm$ 14.74 years old. In the entire group, 44 patients (62.86\%) were under 55 and 26 patients (37.14\%) were over 55 years old at the time of diagnosis. The tumour size largely varied, ranging from $11 \mathrm{~mm}$ to $100 \mathrm{~mm}$, with a mean of $32.32 \pm 21.32 \mathrm{~mm}$.

The low-risk subgroup comprised 23 cases $(32.86 \%)$ of PTC, out of which 16 cases $(22.86 \%)$ were diagnosed as conventional subtype and 7 cases $(10 \%)$, as follicular subtype. The high-risk subgroup included 47 cases $(67.14 \%)$, with the following distribution of the histological variants: columnar cell - 3 cases (4.28\%), tall cell - 15 cases $(21.43 \%)$, cribriform - 6 cases $(8.57 \%)$, hobnail - 1 case $(1.43 \%)$, diffuse sclerosing - 5 cases $(7.14 \%)$, solid - 6 cases $(8.57 \%)$, angioinvasive follicular - 7 cases $(10 \%)$, conventional with dedifferentiation to squamous cell carcinoma - 3 cases $(4.28 \%)$, oncocytic with undifferentiated solid areas - 1 case $(1.43 \%)$.

Multifocality was present in 34 cases (48.57\%), extrathyroidal extension in 55 cases $(78.57 \%)$, and lymphovascular invasion in 47 cases $(67.14 \%)$. Lymph node metastases were found in 24 cases $(47.05 \%)$ - N1a in 13 patients and N1b in 11 patients. According to the WHO guidelines, the Classification of Malignant Tumours (TNM) and the College of American Pathologists Clinical Guidelines, the cases were classified into primary tumour (pT) categories, as follows: pT1 - 4 cases (5.72\%), pT2 - 6 cases $(8.57 \%)$, pT3 - 54 cases $(77.14 \%)$ and pT4 - 6 cases $(8.57 \%)$. Eight patients relapsed, 6 of them were in the highrisk subgroup (diffuse sclerosing type - 2 cases, solid type - 2 cases, angioinvasive follicular type - 1 case, conventional with dedifferentiation to squamous cell carcinoma type - 1 case), and the other two in the low-risk subgroup (conventional variant).

Assessment of $\beta$-tubulin 3 expression

TUBB3 low expression was noted in 3 cases with low intensity of cytoplasmic staining and focal location in less than $50 \%$ of the tumour cells (Figure 1).

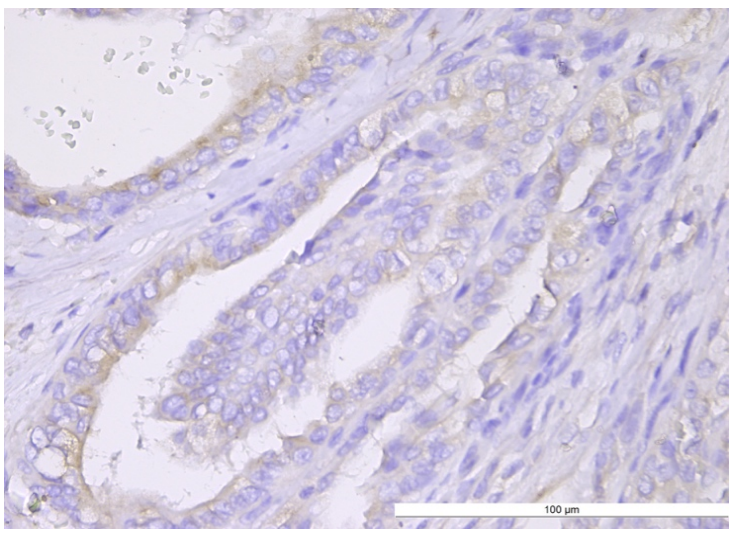

Figure 1.

Focal cytoplasmic immunoreaction of low intensity PTC, conventional subtype (IHC anti-TUBB3, ×400)

A moderate expression was reported in 18 cases, where the cytoplasmic staining intensity was moderate in over $50 \%$ of tumour cells, present either focal or a diffuse pattern in the specimens.

The high expression was assessed in 49 cases; here, the immunoreaction had a strong and homogeneous intensity in almost $100 \%$ of the tumour cells (Figure 2).

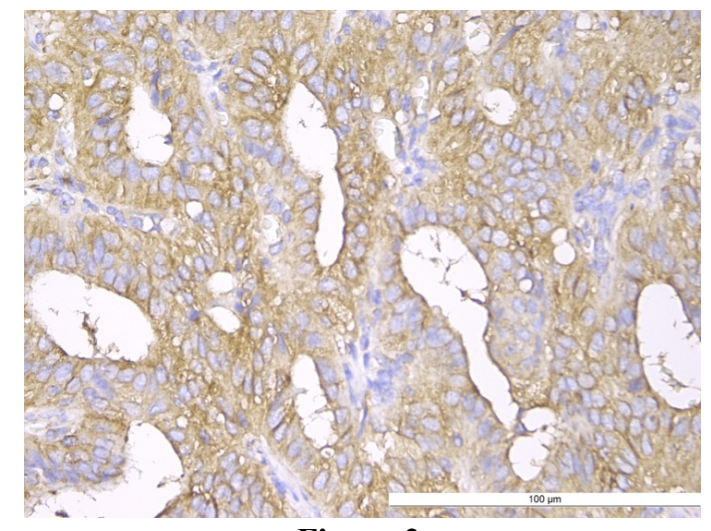

Figure 2.

Diffuse cytoplasmic immunoreaction of strong intensity - follicular subtype (IHC anti-TUBB3, $\times 400$ )

In the adjacent benign thyroid tissue, TUBB3 was negative in all the cases with low and moderate TUBB3 expression in tumour cells, and in 43 out of 49 cases with high expression. Moreover, all relapse cases had negative TUBB3 expression. 
FARMACIA, 2018, Vol. 66, 4

The correspondence between TUBB3 expression and the risk subgroups, was summarized in Table I. the clinico-pathological characteristics, including

Table I

Relationship between TUBB3 expression and clinico-pathological characteristics

\begin{tabular}{|c|c|c|c|}
\hline \multirow{2}{*}{ Clinico-pathological characteristics } & \multicolumn{2}{|c|}{ TUBB-3 expression } & \multirow{2}{*}{ Chi-square test } \\
\hline & low and moderate $(n=21)$ & $\operatorname{High}(n=49)$ & \\
\hline \multicolumn{4}{|l|}{ Age at diagnosis } \\
\hline$<55$ years old & $12(27.3 \%)$ & $32(72.7 \%)$ & \multirow{2}{*}{$\mathrm{p}=0.517$} \\
\hline$\geq 55$ years old & $9(34.6 \%)$ & $17(65.4 \%)$ & \\
\hline \multicolumn{4}{|l|}{ Sex } \\
\hline male & $3(17.6 \%)$ & $14(82.4 \%)$ & \multirow{2}{*}{$\mathrm{p}=0.201$} \\
\hline female & $18(34 \%)$ & $35(66 \%)$ & \\
\hline \multicolumn{4}{|l|}{ Tumour size (median) } \\
\hline$<25 \mathrm{~mm}$ & $8(25 \%)$ & $24(75 \%)$ & \multirow{2}{*}{$\mathrm{p}=0.402$} \\
\hline$\geq 25 \mathrm{~mm}$ & $13(34.2 \%)$ & $25(65.8 \%)$ & \\
\hline \multicolumn{4}{|l|}{ Histopathologic subtype } \\
\hline low risk group & $11(47.8 \%)$ & $12(52.2 \%)$ & \multirow{2}{*}{$\mathrm{p}=0.023$} \\
\hline high risk group & $10(21.3 \%)$ & $37(78.7 \%)$ & \\
\hline \multicolumn{4}{|l|}{ Focality of the tumour } \\
\hline unifocal & $8(22.2 \%)$ & $28(77.8 \%)$ & \multirow{2}{*}{$\mathrm{p}=0.144$} \\
\hline multifocal & $13(38.2 \%)$ & $21(61.8 \%)$ & \\
\hline \multicolumn{4}{|l|}{ Lympho-vascular invasion } \\
\hline absent & $4(17.4 \%)$ & $19(82.6 \%)$ & \multirow{2}{*}{$\mathrm{p}=0.107$} \\
\hline present & $17(36.2 \%)$ & $30(63.8 \%)$ & \\
\hline \multicolumn{4}{|l|}{ Extrathyroidal extension } \\
\hline absent & $3(20 \%)$ & $12(80 \%)$ & \multirow{2}{*}{$\mathrm{p}=0.340$} \\
\hline present & $18(32.7 \%)$ & $37(67.3 \%)$ & \\
\hline \multicolumn{4}{|l|}{ Tumour stage } \\
\hline $\mathrm{T} 1+\mathrm{T} 2$ & $1(10 \%)$ & $9(90 \%)$ & \multirow{2}{*}{$\mathrm{p}=0.136$} \\
\hline $\mathrm{T} 3+\mathrm{T} 4$ & $20(33.3 \%)$ & $40(66.7 \%)$ & \\
\hline \multicolumn{4}{|l|}{ Lymph node metastases } \\
\hline N0 & $7(41.2 \%)$ & $10(58.8 \%)$ & \multirow{2}{*}{$\mathrm{p}=0.158$} \\
\hline N1 & $5(20.8 \%)$ & $19(79.2 \%)$ & \\
\hline \multicolumn{4}{|l|}{ Tumour relapse } \\
\hline absent & $16(25.8 \%)$ & $46(74.2 \%)$ & \multirow{2}{*}{$\mathrm{p}=0.033$} \\
\hline present & $5(62.5 \%)$ & $3(37.5 \%)$ & \\
\hline
\end{tabular}

Correlations between $\beta$-tubulin 3 expression and clinico-pathological prognostic factors

Statistical analysis revealed no correlation between TUBB3 expression (low and moderate versus high) and age, gender, tumour size, tumour focality, lymphovascular invasion, extrathyroidal extension, lymph node metastases and tumour stage. Our results showed significant differences between TUBB3 expression and histological subtypes, defined as risk subgroups, and tumour relapse (Table I).

Expression of $\beta$-tubulin 3 in normal status and malignancies

TUBB3 is usually identified in cells of neuronal origin, where it contributes to the formation of dynamic microtubules which are essential in neurite growth and maintenance $[29,30,36]$. TUBB3 is also expressed in other normal tissues - namely the testicle, small intestine and placenta [35].

The interest in the study of TUBB3 is justified by the part it plays in cell division, an important event in carcinogenesis [28, 38, 46, 60, 78]. Particularities of
TUBB3 expression and distribution are reported in various malignancies including small-cell and nonsmall cell lung cancer $[49,57,69]$, ovarian [50], gastrointestinal $[4,23,85)$, pancreatic, kidney, prostate, breast [35, 36, 58, 78], head and neck [34] tumours. In breast carcinoma, TUBB3 assessment indicates differential expression, according to the histological type, ER (oestrogen receptor) and PR (progesterone receptor) presence, and HER2/neu (human epidermal growth factor receptor 2) status [82]. TUBB3 supraexpression is related to poorly differentiated highgrade [82], triple-negative hormonal status, higher HER2 [36].

In clear-cell renal cell carcinoma [58], TUBB3 expression differs among the histological subtypes, being more frequent in papillary and chromophobe subtypes and oncocytoma compared to clear-cell subtype. In renal cell carcinoma (RCC) clear-cell, TUBB3 overexpression correlates to high Fuhrman grade, advanced stage, lymph node and hematogenous metastases, and shortened overall survival. On the contrary, in the papillary subtype, strong TUBB3 
expression is associated to early tumour stage and overall survival. These variances can be explained by the differences in von Hippel-Lindan tumour suppressive (VHL) function involved in the carcinogenesis of clear-cell and papillary subtype, respectively, because VHL has a similar role to TUBB3, interfering in microtubule stabilization.

In the absence of molecular prognostic factors in bladder carcinoma, recent studies analyse different tubulin isotypes $[7,8,45]$ following advanced stage patients' stratification, to customize the treatment. Another paper indicated the association between the overexpression of $\beta$-tubulin $1, \beta$-tubulin $2, \beta$-tubulin 3 and the tumour degree and stage, as well as shorter disease free survival [9].

TUBB3 analysis in a series of malignant melanoma showed high expression in $80 \%$ cases, but no correlation to classical clinical and pathological variables [73]. Surprisingly enough, TUBB3 decreased expression was associated to survival variables (overall survival and progression-free survival) [73], indicating an unfavourable prognosis.

Overexpression of TUBB3 in colorectal carcinoma, identified in tumour invasion margins $[17,22,56]$, is correlated to the degree of tumour differentiation, lymphatic metastasis [85], poorer prognostic and lower overall survival [44].

Not at last, TUBB3 expression, 4.1 times higher in the uterine serous carcinomas compared to the ovarian serous ones, pleads for its prognostic value $[15,64]$. From tubulin functions to cancer therapy

Due to its functions, tubulin became a target for the development of new therapeutic agents, used in adjuvant chemotherapy applied mainly in breast and ovarian cancer. Taxanes (Paclitaxel, Docetaxel, Cabazitaxel) are a class of drugs that stabilize the microtubules by interfering with spindle microtubule dynamics. Consequently, cell cycle is arrested, apoptosis initiated and tumour progression can be stopped $[47,48]$.

Recent research on the prognostic role of tubulin in several cancers supplements data that sustain its value for predicting the response to neo-adjuvant chemotherapy with taxanes.

Solid evidence published since the 2000s indicate that taxanes improve greatly the evolution of patients with various solid cancers, compared to other therapies. The most relevant example is the breast carcinoma $[6,53]$. Favourable clinical results obtained by using this therapy (i.e. increased pathological complete remission rate in breast carcinoma) are conditioned by lower TUBB3 expression [6]. Additionally, in vitro and in vivo studies showed that TUBB3 can predict paclitaxel chemosensitivity in gastric cancer [83]. On the other hand, several reports showed that TUBB3 overexpression is directly involved in the resistance to taxanes. One of the first reports on this matter, published in 1997, demonstrates an altered expression of specific $\beta$-tubulin genes in taxolresistant ovarian tumours $[31,65,79]$. Supplementary evidence for the relation TUBB3 - chemoresistance is supported by experimental studies, using cancer cell lines [3, 31, 39, 59] and clinical studies. The association between the TUBB3 overexpression, chemoresistance to taxanes and poor prognostic is documented in several malignancies, including breast [6, 20, 53, 76], gastric [80], pancreatic [37], colonic [44] and prostatic [55] carcinomas, clearcell ovarian carcinoma [63], serous uterine carcinoma [64], uterine carcinosarcoma [5], thymic carcinoma $[25,51]$, non-small and small-cell lung carcinoma $[13$, $57,66]$, locally advanced head and neck squamouscell carcinoma [34], as well as in metastatic carcinomas of unknown primary site $[15,19,43,53,71]$.

Nevertheless, discordant results also occur. Other papers show that strong TUBB3 expression is correlated to a favourable response to neo-adjuvant chemotherapy in non-small-cell lung carcinoma [70], clear-cell ovarian carcinoma [2, 15], ER negative breast carcinoma [82], HER2 positive breast carcinoma [24], advanced locally and metastatic breast cancer [16].

This different tumour behaviour reflects various biological characteristics of tubulin, including changes in the $\beta$-tubulin isotype composition in tumour subclones which influences tumour dynamics and the responsiveness of the chemical compounds that interfere with microtubules [30], in relation to the tumour stage (12). The variability of these results is deeply discussed by Jung and co-workers [24]. Their explanations take into account the important differences occurring in the design of various studies, namely the divergences in the group size, tumour stage, histological type and eligible patients [24]. Moreover, the immunohistochemical assessment of TUBB3 uses variable scores and cut-offs, being sometimes doubled by qRT-PCR [12].

Tubulin as potential prognostic marker and target therapeutic agent in thyroid tumours

TUBB3 study in thyroid tumours is limited to anaplastic-cell thyroid carcinoma (the most aggressive and rare solid thyroid tumour, with lethal evolution) in strict relation with the taxane therapy $[1,18]$. A recent research [18] carried out under the coordination of the Working Group of Thyroid Cancer of the Spanish Society of Endocrinology and Nutrition and GETHI of the Spanish Society of Oncology established that for the operable anaplastic-cell thyroid carcinoma, adjuvant chemotherapy must include taxanes [74, 75], associated to doxorubicin, and cisplatin.

Published data referring to TUBB3 expression in PTC are practically inexistent. There are only two reports on TUBB3 immunohistochemical assessment $[10,11]$ in PTC, follicular adenoma, nodular hyperplasia and normal thyroid tissue. The authors 
FARMACIA, 2018, Vol. 66, 4

demonstrated the absence of TUBB3 in the normal follicular epithelium, nodular goitre and follicular adenoma, and a heterogeneous expression in PTC. They noted a negative TUBB3 reaction in the conventional, follicular or encapsulated variant of PTC, and a strong cytoplasmic TUBB3 expression in PTC widely infiltrative associated with fibrous stroma, particularly at the tumour invasive front, and in PTC moderately differentiated, with loss of cell polarity/cohesivity $[10,11]$. Thus, the TUBB3 overexpression in PTC with "aggressive" histological features supports its potential role in invasion and metastasis.

Our study demonstrates low and moderate TUBB3 expression in 21 cases and high expression in 49 cases, and also the correlation with the histological risk subgroups, and tumour relapse. This fact suggests a relationship between TUBB3 and those histological characteristics of PTC that can explain the invasion and metastasis in the cases with poor prognosis. Starting from this idea, the taxanes' efficacy should be proved in those PTC cases that come out from the classic pattern of favourable prognostic, and need a personalized therapy.

\section{Conclusions}

TUBB3 overexpression could be a marker for unfavourable outcome in histological high-risk subgroup of PTC. In addition, the use of taxanes, as specific agents that ensure the microtubules stability, could be considered.

\section{Acknowledgement}

This work was funded by "Grigore T. Popa" University of Medicine and Pharmacy, Iași, Romania, under grant number $31584 / 2015$.

\section{References}

1. Ain KB, Pathobiology of antineoplastic therapy in undifferentiated thyroid cancer. Kluwer Academic Publishers, Boston, 2004; 357-367.

2. Aoki D, Oda Y, Hattori S, Taguchi K, Ohishi Y, Basaki Y, Oie S, Suzuki N, Kono S, Tsuneyoshi M, Ono M, Yanagawa T, Kuwano M, Overexpression of class III beta-tubulin predicts good response to taxane-based chemotherapy in ovarian clear cell adenocarcinoma. Clin Cancer Res., 2009; 15(1): 14731480.

3. Burkhart CA, Kavallaris M, Horwitz SB, The role of beta-tubulin isotypes in resistance to antimitotic drugs. Biochim Biophys Acta, 2001; 1471(2): O1-O9.

4. Carles G, Braguer D, Dumontet C, Bourgarel V, Goncalves A, Sarrazin M, Rognoni JB, Briand C, Differentiation of human colon cancer cells changes the expression of -tubulin isotypes and MAPs. $\mathrm{Br} J$ Cancer, 1999; 80(8): 1162-1168.

5. Carrara L, Guzzo F, Roque DM, Bellone S, Cocco E, Sartori E, Pecorelli S, Schwartz PE, Rutherford TJ,
Santin AD, Differential in vitro sensitivity to patupilone versus paclitaxel in uterine and ovarian carcinosarcoma cell lines is linked to tubulin-beta-III expression. Gynecol Oncol., 2012; 125(1): 231-236.

6. Chen X, Wu J, Lu H, Huang O, Shen K, Measuring $\beta$ tubulin III, $\mathrm{Bcl} 2$, and ERCC1 improves pathological complete remission predictive accuracy in breast cancer. Cancer Sci., 2012; 103(2): 262268.

7. Cheng L, Davison DD, Adams J, Lopez-Beltran A, Wang L, Montironi R, Zhang S, Biomarkers in bladder cancer: Translational and clinical implications. Crit Rev Oncol Hematol., 2014; 89(1): 73-111.

8. Cheng L, Zhang S, Maclennan GT, Williamson SR, Lopez-Beltran A, Montironi R, Bladder cancer: translating molecular genetic insights into clinical practice. Hum Pathol., 2011; 42(4): 455-481.

9. Choi JW, Kim Y, Lee JH, Kim YS, Expression of $\beta$-tubulin isotypes in urothelial carcinoma of the bladder. World J Urol., 2014; 32(2): 347-352.

10. Colato C, Gobbato M, Dardano A, Brazzarola P, Monzani F, Chilosi M, Ferdeghini M, Class IIItubulin expression in papillary thyroid carcinoma: an immunohistochemical assessment. $35^{\text {th }}$ Annual Meeting of the European Thyroid Association Abstracts, Krakow, Poland, 2011: P90, 58.

11. Colato C, Monzani F, Brazzarola P, Martignoni G, Chilosi M, Ferdeghini M, Immunohistochemical expression of [beta] III-tubulin and cell-cell adhesion proteins in papillary thyroid carcinoma: A preliminary report. Endocrine Abstracts, 2012; 29: P1788.

12. Du J, Li B, Fang Y, Liu Y, Wang Y, Li J, Zhou W, Wang X, Overexpression of Class III $\beta$-tubulin, Sox2, and nuclear Survivin is predictive of taxane resistance in patients with stage III ovarian epithelial cancer. BMC Cancer, 2015; 15: 1-11.

13. Dumontet $\mathrm{C}$, Isaac S, Souquet PJ, Bejui-Thivolet F, Pacheco Y, Peloux N, Frankfurter A, Luduena R, Perol $\mathrm{M}$, Expression of class III beta tubulin in non small cell lung cancer is correlated with resistance to taxane chemotherapy. Bull Cancer, 2005; 92: E25 E30.

14. Ferlini C, Raspaglio G, Cicchillitti L, Mozzetti S, Prislei S, Bartollino S, Scambia G, Looking at drug resistance mechanisms for microtubule interacting drugs: does TUBB3 work?. Curr Cancer Drug Targets, 2007; 7(8): 704-712.

15. Ferrandina G, Zannoni GF, Martinelli E, Paglia A, Gallotta V, Mozzetti S, Scambia G, Ferlini C, Class III beta tubulin overexpression is a marker of poor clinical outcome in advanced ovarian cancer patients. Clin Cancer Res., 2006; 12(9): 27742779.

16. Galmarini CM, Treilleux I, Cardoso F, Bernard-Marty C, Durbecq V, Gancberg D, Bissery MC, Paesmans M, Larsimont D, Piccart MJ, Di Leo A, Dumontet C, Class III beta-tubulin isotype predicts response in advanced breast cancer patients randomly treated either with single-agent doxorubicin or docetaxel. Clin Cancer Res., 2008; 14(14): 4511-4516.

17. Giarnieri E, De Francesco GP, Carico E, Midiri G, Amanti C, Giacomelli L, Tucci G, Gidaro S, Stroppa I, Gidaro G, Giovagnoli MR, Alpha- and beta-tubulin expression in rectal cancer development. Anticancer Res., 2005; 25(5): 3237-3241. 
FARMACIA, 2018, Vol. 66, 4

18. Gómez Sáeza JM, Jiménez-Fonsecab P, Santamaría Sandic J, Capdevila Castillónd J, Navarro Gonzáleze E, Zafón Llopisf C, Ramón y Cajal Asensiog T, Riesco Eizaguirreh G, Grande Pulidoi E, Galofré Ferraterj JC, Spanish consensus for the management of patients with anaplastic cell thyroid carcinoma. Endocrinol Nutr., 2015; 62(3): 15-22.

19. Hari M, Yang H, Zeng C, Canizales M, Cabral F, Expression of class III- $\beta$ tubulin reduces microtubule assembly and confers resistance to paclitaxel. Cell Motil Cytoskeleton., 2003; 56(1): 45-56.

20. Hasegawa S, Miyoshi Y, Egawa C, Ishitobi M, Taguchi T, Tamaki Y, Monden M, Noguchi S, Prediction of response to prediction of response to docetaxel by quantitative analysis of class I and III b-tubulin isotype mRNA expression in human breast cancers. Clin Cancer Res., 2003; 9(8): 2992-2997.

21. Hetland TE, Hellesylt E, Flørenes VA, Tropé C, Davidson B, Kærn J, Class III $\beta$ tubulin expression in advanced stage serous ovarian carcinoma effusions is associated with poor survival and primary chemoresistance. Hum Pathol., 2011; 42(7): 10191026.

22. Jirásek T, Cipro S, Musilova A, Kubecová M, Mandys $\mathrm{V}$, Expression of class III beta-tubulin in colorectal carcinomas: An immunohistochemical study using TU-20 \& TuJ-1 antibody. Indian J Med Res., 2009; 129(1): 89-94.

23. Jirasek T, Mandys V, Viklicky V, Expression of class III-tubulin in neuroendocrine tumours of gastrointestinal tract. Folia Histochem Cytobiol., 2002; 40(3): 305-310.

24. Jung M, Koo JS, Moon YW, Park BW, Kim SI, Park $\mathrm{S}$, Lee SH, Hong S, Rha SY, Chung HC, Kim JH, Sohn J, Overexpression of class III beta tubulin and amplified HER2 gene predict good response to paclitaxel and trastuzumab therapy. Plos One, 2012; 7(9): 1-7.

25. Kaira K, Serizawa M, Koh Y, Miura S, Kaira R, Abe M, Nakagawa $K$, Ohde Y, Okumura T, Naito T, Murakami H, Takahashi T, Kondo H, Nakajima T, Endo M, Expression of excision repair crosscomplementation group 1, breast cancer susceptibility 1 , and $\beta$ III-tubulin in thymic epithelial tumors. $J$ Thorac Oncol., 2011; 6(3): 606-613.

26. Kakudo K, Moderate-risk and high-risk thyroid carcinomas of follicular cell origin. JBCM, 2014; 3(1): 12-17.

27. Kakudo K, Tang W, Ito Y, Mori I, Nakamura Y, Miyauchi A, Papillary carcinoma of the thyroid in Japan: subclassification of common type and identification of low risk group. J Clin Pathol., 2004; 57(10): 1041-1046.

28. Karki R, Mariani M, Andreoli M, He S, Scambia G, Shahabi S, Ferlini C, beta III-Tubulin: biomarker of taxane resistance or drug target?. Expert Opin Ther Targets., 2013; 17(4): 461-472.

29. Katsetos CD, Frankfurter A, Christakos S, Mancall EL, Vlachos I, Urich H, Differential localization of class III -tubulin isotype (III) and calbindin-D28k defines distinct neuronal types in the developing human cerebellar cortex. J Neuropathol Exp Neurol., 1993; 52(6): 655-666.

30. Katsetos CD, Herman MM, Mörk SJ, Class III beta tubulin in human development and cancer. Cell Motil Cytoskeleton, 2003; 55(2): 7796.
31. Kavallaris M, Kuo DY, Burkhart CA, Regl DL, Norris MD, Haber M, Horwitz SB, Taxol-resistant epithelial ovarian tumors are associated with altered expression of specific beta-tubulin isotypes. J Clin Invest., 1997; 100(5): 1282-1293.

32. Kilfoy BA, Zheng T, Holford TR, Han X, Ward MH, Sjodin A, Zhang Y, Bai Y, Zhu C, Guo GL, Rothman $\mathrm{N}$, Zhang Y, International patterns and trends in thyroid cancer incidence, 1973-2002. Cancer Causes Control., 2009; 20(5): 525-531.

33. Koh Y, Jang B, Han SW, Kim TM, Oh DY, Lee SH, Kang CH, Kim DW, Im SA, Chung DH, Kim YT, Kim TY, Kim YW, Kim JH, Heo DS, Bang YJ, Expression of class III beta tubulin correlates with unfavorable survival outcome in patients with resected non-small cell lung cancer. $J$ Thorac Oncol., 2010: 5(3): 320-325.

34. Koh Y, Kim TM, Jeon YK, Kwon TK, Hah JH, Lee SH, Kim DW, Wu HG, Rhee CS, Sung MW, Kim $\mathrm{CW}$, Kim KH, Heo DS, Class III beta-tubulin, but not ERCC1, is a strong predictive and prognostic marker in locally advanced head and neck squamous cell carcinoma. Ann Oncol., 2009; 20(8): 1414-1419.

35. Leandro García LJ, Leskelä S, Landa I, Montero Conde C, López Jiménez E, Letón R, Cascón A, Robledo M, Rodríguez Antona C, Tumoral and tissue specific expression of the major human beta tubulin isotypes. Cytoskeleton (Hoboken), 2010; 67(4): 214223.

36. Lebok P, Öztürk M, Heilenkötter U, Jaenicke F, Müller V, Paluchowsk P, Geist S, Wilke C, Burandt E, Lebeau A, Wilczak W, Krech T, Simon R, Sauter G, Guaas A, High levels of class III $\beta$-tubulin expression are associated with aggressive tumor features in breast cancer. Oncol Lett., 2016; 11(3): 1987-1994.

37. Lee LM, Itami A, Pour PM, Hruban RH, Maitra A, Ouellette MM, Class III beta-tubulin, a marker of resistance to paclitaxel, is overexpressed in pancreatic ductal adenocarcinoma and intraepithelial neoplasia. Histopathology, 2007; 51(4): 539-546.

38. Levallet G, Bergot E, Antoine M, Creveuil C, Santos AO, Beau-Faller M, de Fraipont F, Brambilla E, Levallet J, Morin F, Westeel V, Wislez M, Quoix E, Debieuvre D, Dubois F, Rouquette I, Pujol JL, Moro-Sibilot D, Camonis J, Zalcman G; Intergroupe Francophone de Cancérologie Thoracique (IFCT), High TUBB3 expression, an independent prognostic marker in patients with early non-small cell lung cancer treated by preoperative chemotherapy, is regulated by K-Ras signaling pathway. Mol Cancer Ther., 2012; 11(5): 1203-1213.

39. Liu B, Staren ED, Iwamura T, Appert HE, Howard $\mathrm{JM}$, Mechanisms of taxotere-related drug resistance in pancreatic carcinoma. J Surg Res., 2001; 99(2): 179-186.

40. LiVolsi VA, Papillary thyroid carcinoma: an update. Mod Pathol., 2011; 24(Supp12): S1-S9.

41. Lloyd RV, Buehler D, Khanafshar E, Papillary thyroid carcinoma variants. Head Neck Pathol., 2011; 5(1): 51-56.

42. Lloyd RV, Osamura RY, Klöppel G, Rosai J, World Health Organization (WHO) Classification of Tumours of Endocrine Organs, IARC Press, Lyon, 2017; 65-142. 
43. Magnani M, Ortuso F, Soro S, Alcaro S, Tramontano A, Botta $M$, The $\beta-I / \beta$-III- tubulin isoforms and their complexes with antimitotic agent: docking and molecular dynamics studies. FEBS J., 2006; 273(14): 3301-3310.

44. Mariani M, Zannoni G, Sioletic S, Sieber S, Martino C, Martinelli E, Coco C, Scambia G, Shahabi S, Gender influences the Class III and V beta-tubulin ability to predict poor outcome in colorectal cancer. Clin Cancer Res., 2012; 18(10): 2964-2975.

45. Massari F, Bria E, Ciccarese C, Munari E, Modena A, Zambonin V, Sperduti I, Artibani W, Cheng L, Martignoni G, Tortora G, Brunelli M, Prognostic value of beta-tubulin-3 and c-Myc in muscle invasive urothelial carcinoma of the bladder. Plos One, 2015; 10(6): 1-13.

46. McCarroll JA, Gan PP, Erlich RB, Liu M, Dwarte T, Sagnella SS, Akerfeldt MC, Yang L, Parker AL, Chang MH, Shum MS, Byrne FL, Kavallaris M, TUBB3/bIII-tubulin acts through the PTEN/AKT signaling axis to promote tumorigenesis and anoikis resistance in non-small cell lung cancer. Cancer Res., 2015; 75(2): 415-425.

47. McGrogan BT, Gilmartin B, Carney DN, McCann A, Taxanes, microtubules and chemoresistant breast cancer. Biochim Biophys Acta, 2008; 1785(2): 96-132.

48. Nowak AK, Wilcken NR, Stockler MR, Hamilton A, Ghersi D, Systematic review of taxanecontaining versus non-taxane-containing regimens for adjuvant and neoadjuvant treatment of early breast cancer. Lancet Oncol., 2004; 5(6): 372-380.

49. Ohashi T, Yoshimasu T, Oura S, Kokawa Y, Kawago M, Hirai Y, Miyasaka M, Aoishi Y, Kiyoi M, Honda M, Okamura Y, Class III beta-tubulin expression in non-small cell lung cancer: a predictive factor for paclitaxel response. Anticancer Res., 2015; 35(5): 2669-2674.

50. Ohishi Y, Oda Y, Basaki Y, Kobayashi H, Wake N, Kuwano M, Tsuneyoshi M, Expression of beta tubulin isotypes in human primary ovarian carcinoma. Gyneco Oncol., 2007; 105(3): 586592.

51. Okuda K, Oda R, Suzuki A, Tatematsu T, Haneda H, Moriyama S, Yano M, Nakanishi R, Expression of excision repair cross-complementation group 1 and class III $\beta$-tubulin in thymic carcinoma. Oncol Lett., 2017; 13(5): 3144-3150.

52. Orr GA, Verdier Pinard P, McDaid H, Horwitz $\mathrm{SB}$, Mechanisms of taxol resistance related to micro-tubules. Oncogene, 2003; 22(47): 72807295.

53. Paradiso A, Mangia A, Chiriatti A, Tommasi S, Zito A, Latorre A, Schittulli F, Lorusso V, Biomarkers predictive for clinical efficacy of taxol-based chemotherapy in advanced breast cancer. Ann Oncol., 2005; 16: 14-19.

54. Pellegriti G, Frasca F, Regalbuto C, Squatrito S, Vigneri R, Worldwide increasing incidence of thyroid cancer: update on epidemiology and risk factors. $J$ Cancer Epidemiol., 2013; 2013: 1-10.

55. Ploussard G, Terry S, Maillé P, Allory Y, Sirab N, Kheuang L, Soyeux P, Nicolaiew N, Coppolani E, Paule B, Salomon L, Culine S, Buttyan R, Vacherot F, de la Taille A, Class III beta-tubulin expression predicts prostate tumor aggressiveness and patient response to docetaxel-based chemotherapy. Cancer Res., 2010; 70(22): 9253-9264.

56. Portyanko A, Kovalev P, Gorgun J, Cherstvoy E, bIIItubulin at the invasive margin of colorectal cancer: possible link to invasion. Virchows Arch., 2009; 454(5): 541-548.

57. Powell S, Kaizer A, Koopmeiners JS, Iwamoto C, Mark $\mathrm{K}$, High expression of class III $\beta$ tubulin in small cell lung carcinoma. Oncol Lett., 2014; 7(2): 405-410.

58. Quaas A, Rahvar AH, Burdelski C, Koop C, Rink M, Dahlem R, Schlomm T, Tsourlakis MC, Simon R, Minner S, Sauter G, $\beta$ III-tubulin overexpression is linked to aggressive tumor features and shortened survival in clear cell renal cell carcinoma. World $J$ Urol., 2015; 33(10): 1561-1569.

59. Ranganathan S, Benetatos CA, Colarusso PJ, Dexter DW, Altered beta-tubulin isotype expression in paclitaxel-resistant human prostate carcinoma cells. Br J Cancer., 1998; 77(4): 562-566.

60. Raspaglio G, Petrillo M, Martinelli E, Li Puma DD, Mariani M, De Donato M, Filippetti F, Mozzetti S, Prislei S, Zannoni GF, Scambia G, Ferlini C, Sox9 and Hif-2a regulate TUBB3 gene expression and affect ovarian cancer aggressiveness. Gene, 2014; 542(2): 173-181.

61. Roman S, Sosa JA, Aggressive variants of papillary thyroid cancer. Curr Opin Oncol., 2013; 25(1): 33-38.

62. Romero-Rojas A, Cuervo-Martínez J, Osorio-Arango $\mathrm{K}$, Olaya N, Histological variants and prognostic factors of papillary thyroid carcinoma at the Colombian Instituto Nacional de Cancerología, 2006-2012. Biomedica, 2015, 35(3): 429-436.

63. Roque DM, Bellone S, Buza N, Romani C, Cocco E, Bignotti E, Ravaggi A, Rutherford TJ, Schwartz PE, Pecorelli S, Class III b-tubulin overexpression in ovarian clear cell and serous carcinoma as a marker for poor overall survival after platinum/taxane chemotherapy and sensitivity to patupilone. Am J Obstet Gynecol., 2013; 209(1): 62.e1-9.

64. Roque DM, Bellone S, English DP, Buza N, Cocco E, Gasparrini S, Bortolomai I, Ratner E, Silasi DA, Azodi M, Rutherford TJ, Schwartz PE, Santin AD, Tubulin$\beta$-III overexpression by uterine serous carcinomas is a marker for poor overall survival after platinum/taxane chemotherapy and sensitivity to epothilones. Cancer, 2013; 119(14): 2582-2592.

65. Roque DM, Buza N, Glasgow M, Bellone S, Bortolomai I, Gasparrini S, Cocco E, Ratner E, Silasi DA, Azodi M, Rutherford TJ, Schwartz PE, Santin AD, Class III $\beta$-tubulin overexpression within the tumor microenvironment is a prognostic biomarker for poor overall survival in ovarian cancer patients treated with neoadjuvant carboplatin/paclitaxel. Clin Exp Metastasis, 2014; 31(1): 101-110.

66. Rosell R, Scagliotti G, Danenberg KD, Lord RV, Bepler G, Novello S, Cooc J, Crinò L, Sánchez JJ, Taron M, Boni C, De Marinis F, Tonato M, Marangolo M, Gozzelino F, Di Costanzo F, Rinaldi M, Salonga $\mathrm{D}$, Stephens C, Transcripts in pretreatment biopsies from a three arm randomized trial in metastatic non small cell lung cancer. Oncogene, 2003; 22(23): 35483553.

67. Sciuto R, Romano L, Rea S, Marandino F, Sperduti I, Maini CL, Natural history and clinical outcome of 
FARMACIA, 2018, Vol. 66, 4

differentiated thyroid carcinoma: a retrospective analysis of 1503 patients treated at a single institution. Ann Oncol., 2009; 20(10): 1728-1735.

68. Sethi K, Sarkar S, Das S, Mohanty B, Mandal M, Biomarkers for the diagnosis of thyroid cancer. $J$ Exp Ther Oncol., 2010; 8(4): 341-352.

69. Seve P, Dumontet C, Reiman T, Role of tubulin- $\beta$-III in predicting chemoresistance in non-small cell lung cancer. Lung Cancer, 2010; 67(2): 136-143.

70. Sève P, Lai R, Ding K, Winton T, Butts C, Mackey J, Dumontet C, Dabbagh L, Aviel-Ronen S, Seymour L, Whitehead M, Tsao MS, Shepherd FA, Reiman T, Class III $\beta$-tubulin expression and benefit from adjuvant cisplatin/vinorelbine chemotherapy in operable nonsmall cell lung cancer: analysis of NCIC JBR. 10. Clin Cancer Res., 2007; 13(3): 994-999.

71. Seve P, Reiman T, Lai R, Hanson J, Santos C, Johnson L, Dabbagh L, Sawyer M, Dumontet C, Mackey JR, Class III $\beta$-tubulin is a marker of paclitaxel resistance in carcinomas of unknown primary site. Cancer Chemother Pharmacol., 2007; 60(1): 27-34.

72. Sherman SI, Thyroid carcinoma. Lancet, 2003; 361 (9356): 501-511.

73. Shimizu A, Kaira K, Yasuda M, Asao T, Ishikawa $\mathrm{O}$, Decreased expression of class III $\beta$-tubulin is associated with unfavourable prognosis in patients with malignant melanoma. Melanoma Res., 2016; 26(1): 29-34.

74. Shinohara S, Kikuchi M, Naito Y, Fujiwara K, Hori $\mathrm{S}$, Tona Y, Yamazaki H, Ishihara T, Successful treatment of locally advanced anaplastic thyroid carcinoma by chemotherapy and hyperfractionated radiotherapy. Auris Nasus Larynx., 2009; 36(6): 729-732.

75. Sosa JA, Elisei R, Jarzab B, Balkissoon J, Lu SP, Bal C, Marur S, Gramza A, Yosef RB, Gitlitz B, Haugen BR, Ondrey F, Lu C, Karandikar SM, Khuri F, Licitra L, Remick SC, Randomized safety and efficacy study of fosbretabulin withpaclitaxel/carboplatin against anaplastic thyroid carcinoma. Thyroid, 2014; 24(2): 232-240.

76. Tommasi S, Mangia A, Lacalamita R, Bellizzi A, Fedele V, Chiriatti A, Thomssen C, Kendzierski N, Latorre A, Lorusso V, Schittulli F, Zito F, Kavallaris M, Paradiso A, Cytoskeleton and paclitaxel sensitivity in breast cancer: the role of $\beta$-tubulins. Int J Cancer, 2007; 120(10): 2078-2085.

77. Trifanescu RA, Trifanescu OG, Goldstein A, Purice M, Anghel R, Poiana C, Sunitinib, a VEGFR receptor tyrosine kinase inhibitor and its thyroid effects. Farmacia, 2018; 66(2): 331-336.
78. Tsourlakis MC, Weigand P, Grupp K, Kluth M, Steurer S, Schlomm T, Graefen M, Huland H, Salomon G, Steuber T, Wilczak W, Sirma H, Simon R, Sauter G, Minner S, Quaas A, bIII-tubulin overexpression is an independent predictor of prostate cancer progression tightly linked to ERG fusion status and PTEN deletion. Am J Pathol., 2014; 184(3): 609-617.

79. Umezu T, Shibata K, Kajiyama H, Terauchi M, Ino K, Nawa A, Kikkawa F, Taxol resistance among the different histological subtypes of ovarian cancer may be associated with the expression of class III betatubulin. Int J Gynecol Pathol., 2008; 27(2): 207-212.

80. Urano N, Fujiwara Y, Doki Y, Kim SJ, Miyoshi Y, Noguchi S, Miyata H, Takiguchi S, Yasuda T, Yano M, Monden M, Clinical significance of class III beta tubulin expression and its predictive value for resistance to docetaxel based chemotherapy in gastric cancer. Int J Oncol, 2006; 28(2): 375381.

81. Vaccarella S, Dal Maso L, Laversanne M, Bray F, Plummer M, Franceschi S, The impact of diagnostic changes on the rise in thyroid cancer incidence: a population-based study in selected high-resource countries. Thyroid, 2015; 25(10): 1127-1136.

82. Wang Y, Sparano YA, Fineberg S, Stead L, Sunkara J, Horwitz SB, McDaid HM, High expression of class III $\beta$-tubulin predicts good response to neoadjuvant taxane and doxorubicin/cyclophosphamide- based chemotherapy in estrogen receptor-negative breast cancer. Clin Breast Cancer, 2013; 13(2): 103-108.

83. Yu J, Gao J, Lu Z, Gong J, Li Y, Dong B, Li Z, Shen L, Combination of microtubule associated proteintau and $\beta$-tubulin III predicts chemosensitivity of paclitaxel in patients with advanced gastric cancer. Eur J Cancer, 2014; 50(13): 2328-2335.

84. Zhang HL, Ruan L, Zheng LM, Whyte D, Tzeng CM, Zhou XW, Association between class III $\beta$ tubulin expression and response to paclitaxel/vinorebine based chemotherapy for non-small cell lung cancer: A meta analysis. Lung Cancer, 2012; 77(1): 915.

85. Zhao X, Yue C, Chen J, Tian C, Yang D, Xing L, Liu $\mathrm{H}$, Jin Y, Class III b-Tubulin in colorectal cancer: tissue distribution and clinical analysis of chinese patients. Med Sci Monit., 2016; 22: 3915-3924.

86. Zheng WE, Chen H, Yuan SF, Wu LL, Zhang W, Sun HY, Chen WJ, Overexpression of $\beta I I I$ tubulin and survivin associated with drug resistance to docetaxel based chemotherapy in advanced gastric cancer. J BUON., 2012; 17(2): 284290. 